\title{
Cell necrosis and apoptosis are differentially regulated during goitre development and iodine-induced involution
}

\author{
J F Mutaku, J-F Poma ${ }^{1}$, M-C Many, J-F Denef \\ and $\mathbf{M}-\mathrm{F}$ van den Hove ${ }^{1}$ \\ Laboratory of Histology, Catholic University of Louvain, Medical School, Brussels, Belgium \\ ${ }^{1}$ Cell Biology Unit, Catholic University of Louvain and Christian de Duve Institute of Cellular Pathology, Medical School, Brussels, Belgium \\ (Requests for offprints should be addressed to M-F van den Hove, Cell Biology Unit, UCL-ICP, UCL-7541, B-1200, Brussels, Belgium; \\ Email: vandenhove@cell.ucl.ac.be)
}

\begin{abstract}
Necrosis and apoptosis coexist in the thyroid during goitre development and involution, but little is known about their respective causes. To test the possible role of free radicals, we analysed separately necrosis and apoptosis in male Wistar rats with depressed or normal antioxidant protection. Vitamin E-deficient and -sufficient rats were made goitrous with perchlorate in drinking water; involution was induced by repeated injection of $\mathrm{NaI}$, without or with methimazole. Increase of thyroid malondialdehyde concentration and decrease of glutathione peroxidase activity confirmed the depressed antioxidant protection in vitamin E-deficient rats. Plasma thyroxine and TSH levels were not modified. Necrosis (swollen cells) and apoptosis (pyknotic cells) were quantified on histological sections. In vitamin E-sufficient rats, dead cells were very rare in control thyroids, increased 3 -fold in goitre and still further during involution.
\end{abstract}

Necrotic epithelial cells predominated in the goitre and their number declined after iodide supplementation, without or with methimazole. In contrast, the number of apoptotic cells and the caspase- 3 activity were increased in goitre and further increased after involution, with twothirds of pyknotic cells being observed in the interstitium. Apoptosis was prevented by methimazole. Vitamin E deficiency significantly increased total cell death and epithelial cell necrosis and induced the occurrence of much cell debris in the follicular lumen during involution, with no modification of the apoptotic reaction. These results show that the type of cell death is differentially regulated during goitre development and involution: necrosis is related to the oxidative status of the cells, while apoptosis comes with iodine-induced involution.

Journal of Endocrinology (2002) 172, 375-386

\section{Introduction}

Cell proliferation, a hallmark of goitre development, results from increased thyrotropin (TSH) secretion associated with the release of growth factors acting as paracrine or autocrine agents (for review see Derwahl \& Studer 1998). Cell death plays a central role in regulating the thyroid cell mass, especially during the goitre involution induced by iodine or by thyroid hormones (Wollman et al. 1968, Denef et al. 1981, Rognoni et al. 1987). In addition, a balance between cell death and proliferation has also been reported during goitre development itself (Tamura et al. 1998). Indeed, stimulated thyrocytes could be considered as being under oxidative stress: high TSH plasma levels activate $\mathrm{H}_{2} \mathrm{O}_{2}$ production (for review see Dumont et al. 1992) which largely exceeds its consumption by thyroid hormone synthesis (Corvilain et al. 1991). $\mathrm{H}_{2} \mathrm{O}_{2}$ is predominantly produced at the apical plasma membrane but can easily diffuse through the membrane and provoke direct damage to cytoplasmic macromolecules, and even to DNA.

Two types of cell death have been described in the thyroid gland during goitre involution (Mahmoud et al. 1986). Necrosis, or accidental cell death, is characterized by the swelling of the cell, affecting both cytoplasm and nucleus. In contrast, apoptosis, or programmed cell death, corresponds to cytoplasmic shrinkage and nuclear densification (pyknosis). The physiopathology of either type of cell death differs completely. Apoptosis suppression may contribute to thyroid proliferative diseases including goitre, Grave's disease and cancer (Tanimoto et al. 1995). In contrast, necrosis may be involved in the development of autoimmune thyroiditis, favoured upon high iodine supply (Bagchi et al. 1995, Many et al. 1995), and in the development of congenital cretinism upon selenium deficiency (Contempré et al. 1993, 1995).

An acute toxic effect of iodide has been demonstrated in vivo in hypothyroid hamsters (Follis 1964), dogs 
(Belshaw \& Becker 1973), mice (Wollman et al. 1968, Mahmoud et al. 1986) and rats (van den HoveVandenbroucke et al. 1982, Contempré et al. 1995, Many et al. 1995), in obese chicken (Bagchi et al. 1995) and in human thyroid follicles in vitro (Many et al. 1992).

Intrathyroidal apoptotic cells were first detected in human chronic autoimmune thyroiditis by Kotani et al. (1995) and Tanimoto et al. (1995). More recently, apoptosis has been reported during goitre formation in rats, with a further increase during the early stage of goitre involution with normal (Patel et al. 2000) or high iodine doses (Tamura et al. 1998), but the respective roles of apoptosis and necrosis were not quantified.

In vitro, apoptosis can be induced in thyrocytes under various culture conditions: deprivation of TSH and serum (Dremier et al. 1994), addition of cytokines (Kawakami et al. 1996, Bretz et al. 1999), direct exposure to $\mathrm{H}_{2} \mathrm{O}_{2}$ (Riou et al. 1999), and even iodide in excess (Feldkamp et al. 1999, Vitale et al. 2000). Apoptosis results also from the loss of normal integrin-fibronectin interactions (anoikis) (Di Matola et al. 2000), and is prevented by TSH (Li et al. 1999, Sato et al. 1999). In addition, when thyroid follicles are cultured in a three-dimensional system, even withdrawal of TSH or other growth factors does not induce apoptosis (Bechtner et al. 1999) suggesting that two-dimensional models of cultured thyrocytes do not reflect the in vivo regulation of apoptosis.

The cytotoxicity of excess iodine includes necrotic and apoptotic features. Whether either type of cell death is due to the formation of reactive oxidative radicals in excess, as previously suggested (Denef et al. 1996), remains to be established in vivo. As do many other organs, the thyroid contains antioxidative defences, among which are enzymes with antioxidant properties. For example, glutathione peroxidase (GPx) activity is increased during goitre development, as well as in human hyperactive pathologies (Mano et al. 1997) and in isolated cells stimulated by TSH (Björkman \& Ekholm 1995). Recently, the expression of peroxiredoxins, very effective antioxidant enzymes (Knoops et al. 1999), has been reported to be modulated by TSH (Kim et al. 2000).

Besides enzymatic systems, cells are also protected by several intracellular vitamins. Vitamin E plays a major role in the maintenance of membrane integrity, being both a strong free radical scavenger and a structural stabilizer (Gutteridge 1978). Its depletion results in increased lipid peroxidation (Machlin et al. 1977, Walsh et al. 1993) and thus represents an appropriate in vivo model to analyse the role of oxidative stress radicals in the induction of cell death. In the present study, we compared the extent of intrathyroidal necrosis and apoptosis during goitre formation and iodine-induced involution in rats fed a vitamin E-deficient or -sufficient diet. In addition, we paid attention to the location of the apoptotic cells. Indeed, a high number in the interstitial tissue may be of great pathological significance.

\section{Materials and Methods}

\section{Animals and treatments}

Three-week-old male Wistar rats (KUL, Leuven, Belgium), weighing approximately $40 \mathrm{~g}$ at the onset of the study, were fed a basal vitamin E-deficient diet $(<15 \mathrm{mg} / \mathrm{kg}$, AO3; Usine d'Alimentations Rationnelles (UAR), Epinay-sur-Orge, France) without $\left(\mathrm{E}^{-}\right)$or with $\left(\mathrm{E}^{+}\right) \quad 170 \mathrm{mg} / \mathrm{kg}$ vitamin $\mathrm{E}$ (dl- $\alpha$-tocopherol acetate; UAR). This diet contained $480 \mu \mathrm{g}$ iodine and $100 \mu \mathrm{g}$ selenium per $\mathrm{kg}$, representing a daily supply of about 6 and $1.3 \mu \mathrm{g}$ respectively. Rats were maintained in accordance with the principles of laboratory animal care. They were housed two per cage, in a temperature- and lightcontrolled room and had free access to water and their respective diets for 2 months. No specific feeding behaviour was noticed between $\mathrm{E}^{+}$and $\mathrm{E}^{-}$rats. The mean daily intake per rat was about 12-13 g dry food in both groups. However, after 2 months on these diets, the body weight gain was significantly smaller in the $\mathrm{E}^{-}$groups than in the $\mathrm{E}^{+}$groups $(163 \pm 20$ vs $235 \pm 27 \mathrm{~g}$ (S.D.), $P<0 \cdot 01, n=20$ ).

Groups of rats were thereafter made goitrous with $1 \%$ sodium perchlorate in the drinking water for 16 days, while control groups received tap water. During this treatment, the body weight gain was not significantly different in $\mathrm{E}^{+}$and $\mathrm{E}^{-}$groups, at $23 \pm 12$ and $17 \pm 10 \mathrm{~g}$ respectively $(n=15)$.

To induce goitre involution, some goitrous rats were then injected daily with $200 \mu \mathrm{g} \mathrm{NaI}$ i.p. for 3 days, perchlorate being withdrawn or replaced by $0.02 \%$ methimazole (MMI) (Merck, Darmstadt, Germany), an inhibitor of iodine oxidation.

Treatments led thus to eight different groups, of five rats each: control, goitre, involution without or with MMI, each with or without vitamin E.

Rats were killed under Nembutal anaesthesia $24 \mathrm{~h}$ after the last $\mathrm{NaI}$ injection. Blood was collected by cardiac puncture and plasma was stored at $-20{ }^{\circ} \mathrm{C}$ until use. For biochemical determinations, one lobe of each thyroid gland was directly dissected, weighed, quick-frozen in liquid nitrogen and stored at $-80^{\circ} \mathrm{C}$. Frozen individual lobes were homogenized by grinding in $100 \mathrm{mM} \mathrm{KCl}$, $20 \mathrm{mM}$ phosphate buffer ( $\mathrm{pH} 7 \cdot 4$ ), for GPx and caspase3/apopain activities, malondialdehyde (MDA), DNA, iodine and protein content determinations.

For a control, pieces of liver were also quickly frozen for MDA determination, or prepared for microscopy in order to check a possible toxic effect of either vitamin $\mathrm{E}$ deficiency or perchlorate on hepatocytes. No alteration was seen in any group.

\section{Morphological and stereological analysis}

After the dissection of one thyroid lobe, rats were perfused through the heart with saline for $1 \mathrm{~min}$, then with $2 \cdot 5 \%$ glutaraldehyde in $0 \cdot 1 \mathrm{M}$ cacodylate buffer $(\mathrm{pH} 7 \cdot 4)$, for 
Table 1 Plasma $\mathrm{T}_{3}, \mathrm{~T}_{4}$ and TSH (means \pm S.D., $n=5$ ) in control rats, rats made goitrous with $1 \%$ sodium perchlorate in drinking water for 16 days and goitrous rats injected daily i.p. with $200 \mu \mathrm{g}$ Nal for 3 days without (involution) or with methimazole (MMI)

\begin{tabular}{|c|c|c|c|c|}
\hline & Vitamin E & $\begin{array}{l}\mathbf{T}_{3} \\
(\mathrm{ng} / \mathrm{dl})\end{array}$ & $\begin{array}{l}\mathbf{T}_{\mathbf{4}} \\
(\mu \mathrm{g} / \mathrm{dl})\end{array}$ & $\begin{array}{l}\text { TSH } \\
(\mathrm{ng} / \mathrm{ml})\end{array}$ \\
\hline \multicolumn{5}{|l|}{ Group } \\
\hline \multirow[t]{2}{*}{ Control } & + & $64 \cdot 8 \pm 6 \cdot 8$ & $1 \cdot 39 \pm 0 \cdot 3$ & $17 \cdot 8 \pm 4 \cdot 7$ \\
\hline & - & $79 \cdot 4 \pm 9 \cdot 2$ & $1 \cdot 68 \pm 0.5$ & $16 \cdot 6 \pm 3 \cdot 3$ \\
\hline \multirow[t]{2}{*}{ Goitre } & + & $21 \cdot 2 \pm 4 \cdot 4^{\circ+}$ & $<1 \cdot 25^{\circ+}$ & $71 \cdot 6 \pm 18 \cdot 0^{\circ+}$ \\
\hline & - & $17 \cdot 6 \pm 3 \cdot 1^{\circ+}$ & $<1 \cdot 25^{\circ+}$ & $83 \cdot 6 \pm 14 \cdot 0^{\circ+}$ \\
\hline \multirow[t]{2}{*}{ Involution } & + & $48 \cdot 8 \pm 9 \cdot 9^{*}$ & $2 \cdot 40 \pm 0 \cdot 3^{\circ+}$ & $29 \cdot 7 \pm 7 \cdot 2^{*}$ \\
\hline & - & $52 \cdot 8 \pm 12 \cdot 0^{*}$ & $1 \cdot 86 \pm 0 \cdot 3^{\circ+}$ & $24 \cdot 0 \pm 2 \cdot 5^{*}$ \\
\hline \multirow[t]{2}{*}{ Involution + MMI } & + & $32 \cdot 6 \pm 15 \cdot 0^{\circ}$ & $<1 \cdot 25^{\circ+}$ & $83 \cdot 3 \pm 11 \cdot 0^{\circ+}$ \\
\hline & - & $34 \cdot 6 \pm 24 \cdot 0^{\circ}$ & $<1 \cdot 25^{\circ+}$ & $86 \cdot 0 \pm 26 \cdot 0^{\circ+}$ \\
\hline
\end{tabular}

${ }^{\circ} P<0.05$ vs $\mathrm{E}^{+}$control rats; ${ }^{*} P<0.05$ vs goitre with or without vitamin $\mathrm{E} ;{ }^{+} P<0.05$ vs involution with or without vitamin $\mathrm{E}$.

$5 \mathrm{~min}$. The second thyroid lobe was carefully dissected, weighed and processed for light and electron microscopy (Many et al. 1992); after a further fixation in the same fixative, thyroid fragments were postfixed in $1 \%$ osmium tetroxide, dehydrated and embedded in plastic. Semi-thin sections $(0.5 \mu \mathrm{m})$ were cut from the centre of each fragment and stained with toluidine blue. Ultrathin sections from adequate areas selected on semi-thin sections were stained with 3\% uranyl acetate and 2.5\% lead citrate and observed on a Philips CM12 electron microscope (Philips, Eindhoven, Holland), to confirm at the ultrastructural level events defined as necrosis or apoptosis at the light microscopy level.

The extent of cell death by necrosis or apoptosis was quantified from semi-thin sections at $\times 500$ magnification by counting two whole sections per gland, based on 15-20 fields per section. Results were expressed per field ( $\sim 100$ cells). Cells with swollen aspect and/or pale cytoplasm and nuclei were defined as necrotic. Shrunken cells, with dense pyknotic nuclei, or with accumulation of apoptotic bodies were defined as apoptotic. Necrotic and apoptotic cells were counted separately in the follicular epithelium or in the interstitium. Dying cells and cell debris present in the follicular lumina were also numbered but the distinction between necrotic or apoptotic features could not be made. Relative volumes of glandular compartments (epithelium, follicular lumina, blood vessels and non-vascular interstitium) were determined by the point counting method as described (Denef et al. 1981). All measurements and analyses were made blind of the animal code.

\section{Thyroid hormone assays}

Concentrations of plasma thyroid hormones were determined in duplicate by RIA using commercially available kits for tri-iodothyronine $\left(\mathrm{T}_{3}\right)$ and thyroxine $\left(\mathrm{T}_{4}\right)$ (Corning, Meldfield, MA, USA). Plasma TSH concentrations were determined using a specific kit for rat TSH (Amersham International, Amersham, Bucks, UK).

\section{$D N A$, iodine and protein determination}

DNA and stable iodine were determined on the individual thyroid homogenates as described (van den Hove et al.

Table 2 Thyroid glandular parameters (means \pm S.D., $n=5$ ). Same protocol as in Table 1

\begin{tabular}{|c|c|c|c|c|c|c|c|}
\hline & Vitamin E & $\begin{array}{l}\text { Relative } \\
\text { weight } \\
(\mu \mathrm{g} / \mathrm{g})\end{array}$ & $\begin{array}{l}\text { DNA } \\
(\mu \mathrm{g} / \mathrm{mg})\end{array}$ & $\begin{array}{l}\text { Iodine } \\
\text { (ng/mg) }\end{array}$ & \multicolumn{3}{|c|}{ Relative volume of compartments (\%) } \\
\hline \multicolumn{8}{|l|}{ Group } \\
\hline \multirow{2}{*}{ Control } & + & $53 \pm 1$ & $3 \cdot 3 \pm 0 \cdot 7$ & $719 \pm 224$ & $45 \pm 1 \cdot 9$ & $25 \pm 1 \cdot 1$ & $10 \pm 1 \cdot 2$ \\
\hline & - & $66 \pm 1^{\circ}$ & $3 \cdot 1 \pm 0 \cdot 8$ & $871 \pm 84$ & $44 \pm 1 \cdot 1$ & $25 \pm 1 \cdot 1$ & $11 \pm 1 \cdot 6$ \\
\hline Goitre & + & $155 \pm 2^{\circ}$ & $2 \cdot 9 \pm 0 \cdot 7$ & $31 \pm 19$ & $47 \pm 1 \cdot 8$ & $0 \cdot 9 \pm 0 \cdot 3^{\circ+}$ & $35 \pm 2 \cdot 2^{\circ}$ \\
\hline Involution & - & $112 \pm 2^{\circ *}$ & $3 \cdot 5 \pm 0 \cdot 2$ & $396 \pm 135$ & $47 \pm 3 \cdot 4$ & $11 \pm 2 \cdot 1^{\circ *}$ & $23 \pm 3 \cdot 0^{\circ *}$ \\
\hline \multirow[t]{2}{*}{ Involution + MMI } & + & $133 \pm 2^{\circ+}$ & $3 \cdot 2 \pm 0 \cdot 7$ & $17 \pm 10$ & $45 \pm 1.9$ & $3 \cdot 6 \pm 0 \cdot 5^{\circ+}$ & $33 \pm 2 \cdot 3^{\circ+}$ \\
\hline & - & $152 \pm 4^{\circ+}$ & $3 \cdot 2 \pm 0 \cdot 3$ & $48 \pm 30$ & $44 \pm 2 \cdot 0$ & $6 \cdot 0 \pm 3 \cdot 3^{\circ+}$ & $32 \pm 4 \cdot 1^{\circ+}$ \\
\hline
\end{tabular}

${ }^{\circ} \mathrm{P}<0.05$ vs $\mathrm{E}^{+}$control rats; ${ }^{*} P<0.05$ vs goitre with or without vitamin $\mathrm{E} ;{ }^{+} P<0.05$ vs involution with or without vitamin $\mathrm{E}$. 

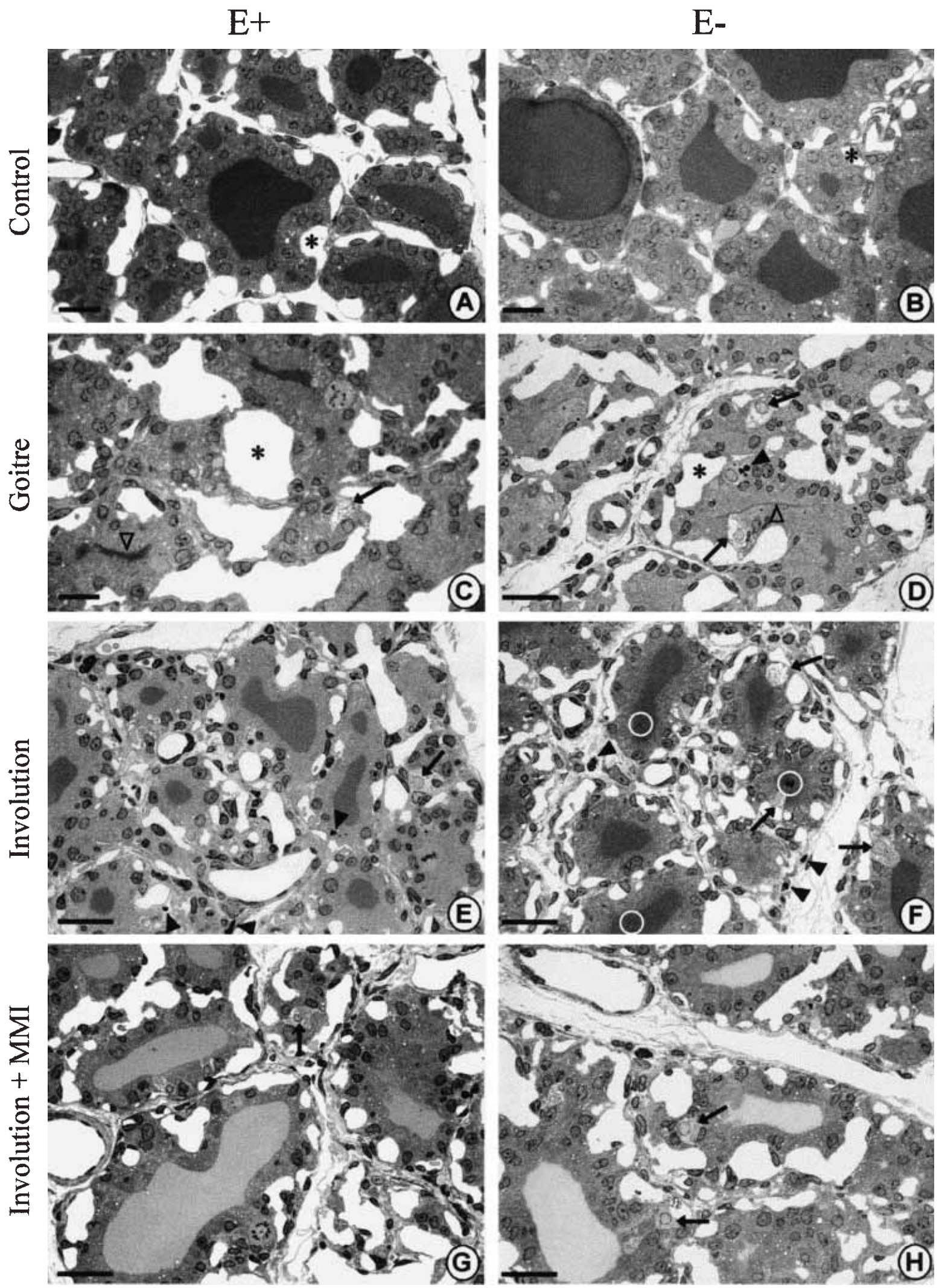
1995). Total protein was measured with the Bio-Rad protein assay (Bio-Rad Laboratories, Munich, Germany) using BSA as standard.

\section{Thyroid and liver MDA levels determination}

The level of lipid peroxides in thyroid and liver tissues was determined by measuring the reaction of MDA with 2-2-thiobarbituric acid (Janssen Chemica, Geel, Belgium) according to Bidder \& Sipka (1989). MDA levels were normalized for DNA content.

\section{GPx activity determination}

GPx activity was determined according to Ekholm \& Björkman (1997) and expressed in nanomoles of NADPH oxidized, i.e. $\mathrm{H}_{2} \mathrm{O}_{2}$ degraded, per min and per $\mathrm{mg}$ of DNA.

\section{Caspase-3/apopain activity determination}

Caspase-3/apopain activity was determined with the FluoroAce Apopain assay kit, according to the manufacturer's instructions (Bio-Rad).

\section{Statistical analysis}

Results are expressed as means \pm s.D. $(n=5)$. Comparisons between groups were made by one- or two-way ANOVA followed by an F-test. Significant differences between means were performed after ANOVA by the least significant differences test. The overall variation coefficient of the point counting method was about 6\% (Many et al. 1992). For morphometric analysis, differences were considered as significant when $P<0 \cdot 05$ (not significant $=\mathrm{ns}$ ). A logarithmic transformation was applied to data from the analysis of follicular necrotic and apoptotic cells before the ANOVA.

\section{Results}

Vitamin E deficiency does not affect thyroid hormone concentrations in plasma during goitre development and involution

Plasma $\mathrm{T}_{3}$ and $\mathrm{T}_{4}$ levels were not different in control $\mathrm{E}^{+}$ and $\mathrm{E}^{-}$rats, but markedly depressed after 16 days of goitre development (Table 1). They were significantly increased after 3 days of high iodide supply, suggesting the absence of an inhibitory Wolff-Chaikoff effect. Administration of MMI together with iodide to goitrous animals blocked the iodine-induced rise in hormone levels. Vitamin E deficiency did not significantly modify $\mathrm{T}_{3}$ and $\mathrm{T}_{4}$ levels whatever the experimental group.

Plasma TSH level was increased significantly at day 16 of goitre development and returned close to control values after iodide supplementation for 3 days. MMI given to goitrous rats abolished this decrease. Vitamin E deficiency had no effect.

Size and DNA content of the goitre induced in vitamin E-deficient rats are proportional to animal growth

In controls, the absolute thyroid weight was significantly smaller in $\mathrm{E}^{-}$rats, while the thyroid/body weight ratio was slightly increased $(P<0 \cdot 05)$ (Table 2$)$. After 16 days of goitre development, thyroid weights increased 3- and 2 -fold in $\mathrm{E}^{+}$and $\mathrm{E}^{-}$rats respectively. After 3 days of iodide administration, glandular weight decreased significantly in all treated rats, although remaining higher than in controls. This decrease was blocked by MMI.

In control groups, thyroid contained $23 \pm 5 \mu \mathrm{g}$ DNA/ lobe in $\mathrm{E}^{+}$animals and $20 \pm 5 \mu \mathrm{g}$ DNA/lobe in $\mathrm{E}^{-}$ animals. In $\mathrm{E}^{+}$rats, the thyroid DNA content rose to $63 \pm 11 \mu \mathrm{g} /$ lobe $(P<0 \cdot 001)$ during goitre and decreased to $41 \pm 8 \mu \mathrm{g} /$ lobe $(P<0 \cdot 01)$ during involution, while remaining high with $\mathrm{MMI}(65 \pm 10 \mu \mathrm{g} / \mathrm{lobe})$. In $\mathrm{E}^{-}$ animals, the DNA content increased to $45 \pm 4 \mu \mathrm{g} /$ lobe $(P<0 \cdot 01)$ during goitre development and was not reduced after iodine treatment without or with MMI. The DNA content varied largely in parallel with the thyroid weight.

After 16 days of perchlorate treatment, the iodine concentration decreased from $719 \pm 224 \mathrm{ng} / \mathrm{mg}$ of tissue in control rats to $31 \pm 18 \mathrm{ng} / \mathrm{mg}$ of tissue in goitrous rats. After iodide administration to goitrous rats, the thyroid iodine concentration remained about half the value observed in controls. MMI administration maintained the iodine concentration close to goitrous values. Changes observed in $\mathrm{E}^{-}$animals did not differ from those observed in $\mathrm{E}^{+}$animals.

Figure 1 (Opposite). General thyroid histology. (A, B) Control rats received a vitamin $E\left(E^{+}\right)(A)$ or $E^{-}$(B) diet. Glands have a normal morphology and the blood vessels are not dilated (asterisks). (C, D) $E^{+}(C)$ or $E^{-}$(D) rats were made goitrous by drinking perchlorate. Blood vessels are markedly enlarged (asterisks), epithelial cells are hypertrophic and follicular lumina are very narrow (empty arrowheads). Some follicular necrotic cells are present in the epithelial wall (arrows). No effect of vitamin E deficiency is noticed on the thyroid morphology, but the proportion of follicular necrotic cells is increased in the $\mathrm{E}^{-}$goitrous thyroid. Note also the presence of apoptotic bodies in this condition (arrowhead). (E, F) Goitres in $E^{+}(E)$ or $E^{-}(F)$ rats were caused to involute by repeated Nal injections. Blood vessels are constricted as compared with $(C)$ and $(D)$. Follicular lumina are widened and contained a dense colloid. Some follicular necrotic cells are present in the epithelial wall (arrows). Vitamin E deficiency increases the number of necrotic cells (arrows) without altering the thyroid morphology. Note the presence of cell fragments in the follicular lumina (open circles) and of several apoptotic cells in the epithelium as well as in the interstitium (arrowheads). $(\mathrm{G}, \mathrm{H}) \mathrm{E}^{+}(\mathrm{G})$ or $\mathrm{E}^{-}(\mathrm{H})$ rats received Nal plus methimazole (MMI). Some blood vessels are constricted. Follicular lumina are widened or narrow. Some follicular necrotic cells are observed in the epithelial wall (arrows). Bars $=20 \mu \mathrm{m}$. 
Protein content showed the same evolution as DNA and was not affected by vitamin E deficiency.

Vitamin E deficiency aggravates epithelial cell necrosis without influencing cell apoptosis during goitre development and involution

In both $\mathrm{E}^{+}$and $\mathrm{E}^{-}$control animals, thyroid contained normal large follicular lumina lined by a cuboidal epithelial layer. The follicles were surrounded by capillaries with very thin lumina (Fig. 1A and B).

A typical hyperplastic goitre was formed after 16 days of perchlorate treatment (Fig. 1C). The follicular lumina were narrow, and lined by a thickened epithelium with hypertrophied cylindrical cells and numerous mitotic figures. Blood vessels were markedly enlarged as confirmed by the morphometric analysis (Table 2 ). In contrast, the relative volumes of epithelium (Table 2) and of non-vascular interstitium (data not shown) were not modified. Again, vitamin E deficiency had little influence on the morphology and on the morphometric parameters of goitrous glands, except that more numerous necrotic cells were seen in the epithelial layer (Fig. 1D).

After 3 days of iodine-induced goitre involution, the follicular lumina were slightly but significantly widened (Table 2) and contained a dense colloid. Blood capillaries were constricted and typical dense pyknotic nuclei were observed either in the epithelial wall or in the insterstitium (Fig. 1E). In $\mathrm{E}^{-}$animals, follicular lumina size and blood capillary constriction were similar to those observed in $\mathrm{E}^{+}$ ones (Fig. 1F). Meanwhile, cellular debris was more numerous in some follicular lumina. Apoptotic cells were also observed, either in the epithelial wall, or in the interstitium. A very modest inflammatory cell infiltration was observed in the interstitium or in the follicles in either group.

After administration of iodide with MMI to the iodinedeficient rats, the follicular lumina were slightly dilated, containing a pale colloid, and the blood vessels were still enlarged. The gland aspect was similar in both $\mathrm{E}^{-}$ (Fig. $1 \mathrm{H}$ ) and $\mathrm{E}^{+}$animals (Fig. 1G). Cell death was not as frequent as after iodine administration alone. The iodineinduced expansion of the follicular lumina and the reduction of blood vessels observed during involution were partly impaired (Table 2). Again, vitamin E deficiency did not alter any of these parameters.

Apoptosis and necrosis were confirmed at the ultrastructural level. The dense inclusions, often rounded, sometimes elongated, seen in the interstitium or in the basal pole of the epithelial follicular cells on semi-thin sections (Fig. 2A) corresponded to condensed nuclei with very dense chromatin (Fig. 2B). On the contrary, faintly coloured cells, often with a round shape (Fig. 2A), consisted of necrotic cells with diluted or vacuolated cytoplasm and numerous damaged organelles (Fig. 2C).
Debris present in the follicular lumina was often dense (Fig. 2D) but some was pale in aspect.

Results of counting for necrotic or apoptotic cells are reported in Fig. 3. The total number of dead cells per field was low in control thyroids and significantly increased in goitrous glands of $\mathrm{E}^{+}$or $\mathrm{E}^{-}$animals (Fig. 3A). It further increased during involution, mainly in the $\mathrm{E}^{-}$group, while it was not changed in the presence of MMI. A significant proportion of the total dead cells observed during involution corresponded to interstitial cells, whatever the vitamin E supply. These cells were almost all in apoptosis. In addition, intracolloidal cell debris was mainly observed during involution in the $\mathrm{E}^{-}$group.

An overall significant increase in epithelial dead cells was noticed in the $\mathrm{E}^{-}$groups (Fig. 3). The proportion of dead thyrocytes was 3-fold increased during goitre development, including mostly cells with a necrotic aspect (Fig. 3B), but not further increased when iodine was administered alone or in association with MMI. The proportion of epithelial necrotic cells slightly decreased in the $\mathrm{E}^{+}$animals as compared with the goitre condition when iodine was administered, alone or with MMI. This decrease was not observed in the $\mathrm{E}^{-}$group. Epithelial apoptosis was mainly increased during involution, with no significant difference upon vitamin treatment (Fig. 3B). Caspase-3/apopain activity, an indicator of apoptosis biochemistry, was not detected in control glands, increased in goitres and further increased during involution (Table 3). The effect of vitamin E supply taken as a whole was not significant, differences between $\mathrm{E}^{+}$and $\mathrm{E}^{-}$values varying in an opposite way in goitre and involution.

Vitamin E deficiency increases MDA concentration and decreases GPx activity in the thyroid

In $\mathrm{E}^{+}$control rats, the MDA concentration in the thyroid tissue $(82 \cdot 9 \pm 19 \cdot 0 \mathrm{nmol} / \mathrm{mg}$ DNA) was one-third of the values observed in the liver of the same animals $\left(276 \cdot 0 \pm 46 \cdot 7 \mathrm{nmol} / \mathrm{mg}\right.$ DNA). In $\mathrm{E}^{-}$animals, the increase was proportionally higher in the thyroid $(144.5 \pm 32.6 \mathrm{nmol} / \mathrm{mg}$ DNA) than in the liver $(352.7 \pm 58.3 \mathrm{nmol} / \mathrm{mg}$ DNA, $P<0.001)$. The thyroid MDA concentration was not changed during the goitrogenic treatment whatever the vitamin E supply (Fig. 4A). The thyroid MDA concentration rose slightly but significantly in $\mathrm{E}^{+}$goitrous rats exposed to iodine in excess. This effect was absent in the presence of MMI. ANOVA analysis clearly demonstrated a significant increase of the MDA concentration, as a whole, in $\mathrm{E}^{-}$animals as compared with $\mathrm{E}^{+}$ones.

GPx activity increased significantly during goitre development and was not changed after iodine treatment (Fig. 4B). ANOVA analysis showed a significant general decrease of GPx activity in $\mathrm{E}^{-}$groups, which was aggravated after 3 days of iodine involution without MMI. 

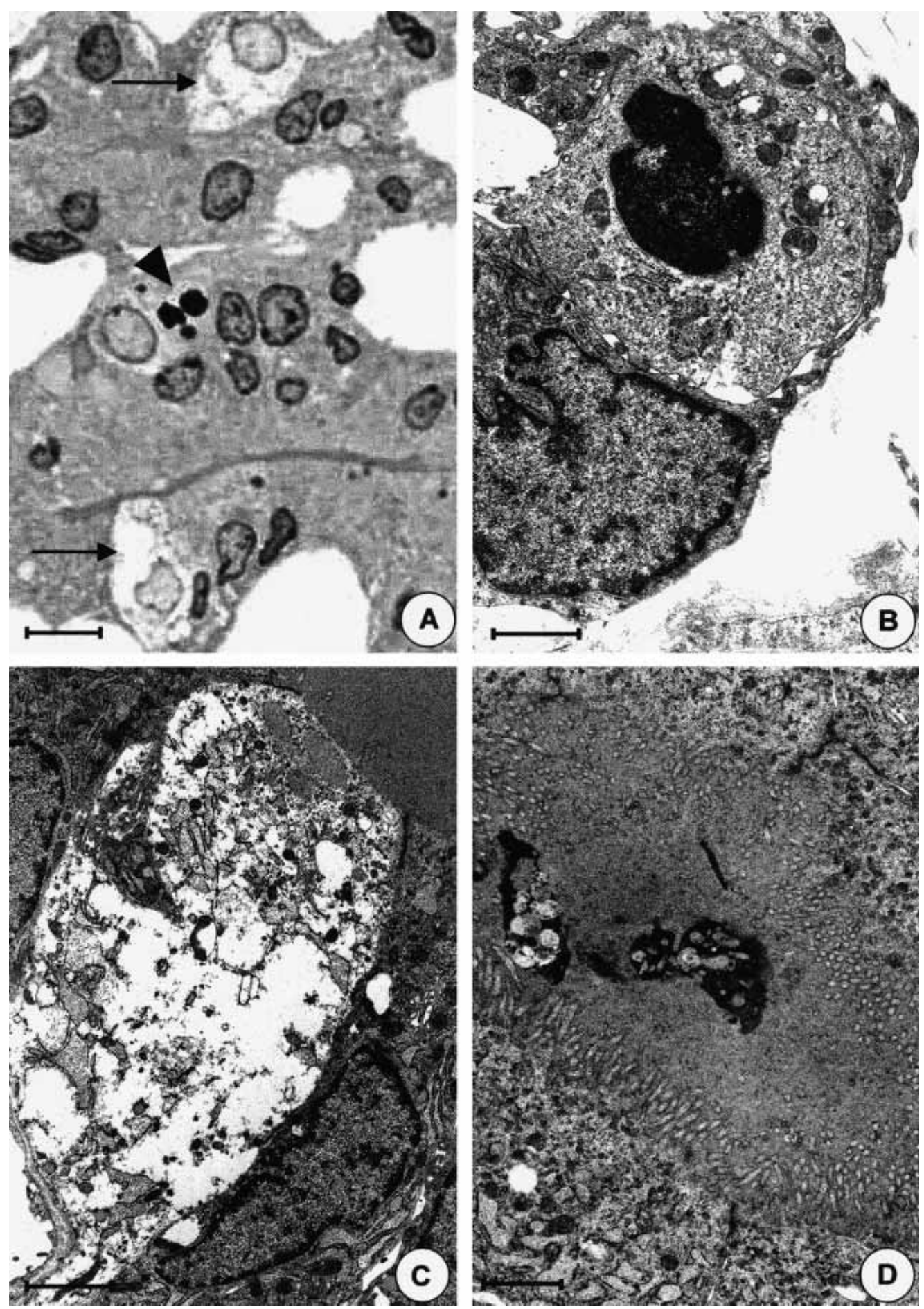

Figure 2 Characteristic aspects of necrosis and apoptosis by light (A) and electron (B-D) microscopy. (A) $\mathrm{E}^{-}$ goitrous rat; bar $=5 \mu \mathrm{m}$. Two necrotic cells (arrows) are visible in the epithelial wall; nuclei are pale and cytoplasms are swollen and vacuolar. Apoptotic bodies correspond to fragmented pyknotic nuclei (arrowhead). (B-D) Nal-treated $\mathrm{E}^{-}$goitrous rats; bar $=1 \mu \mathrm{m}$. Necrosis corresponds to organelle swelling and disruption (C). Apoptotic bodies are endocytosed in the interstitium (B). Note that cell debris is often very dense in the follicular lumen (D). 


\section{A : Total dead cells}

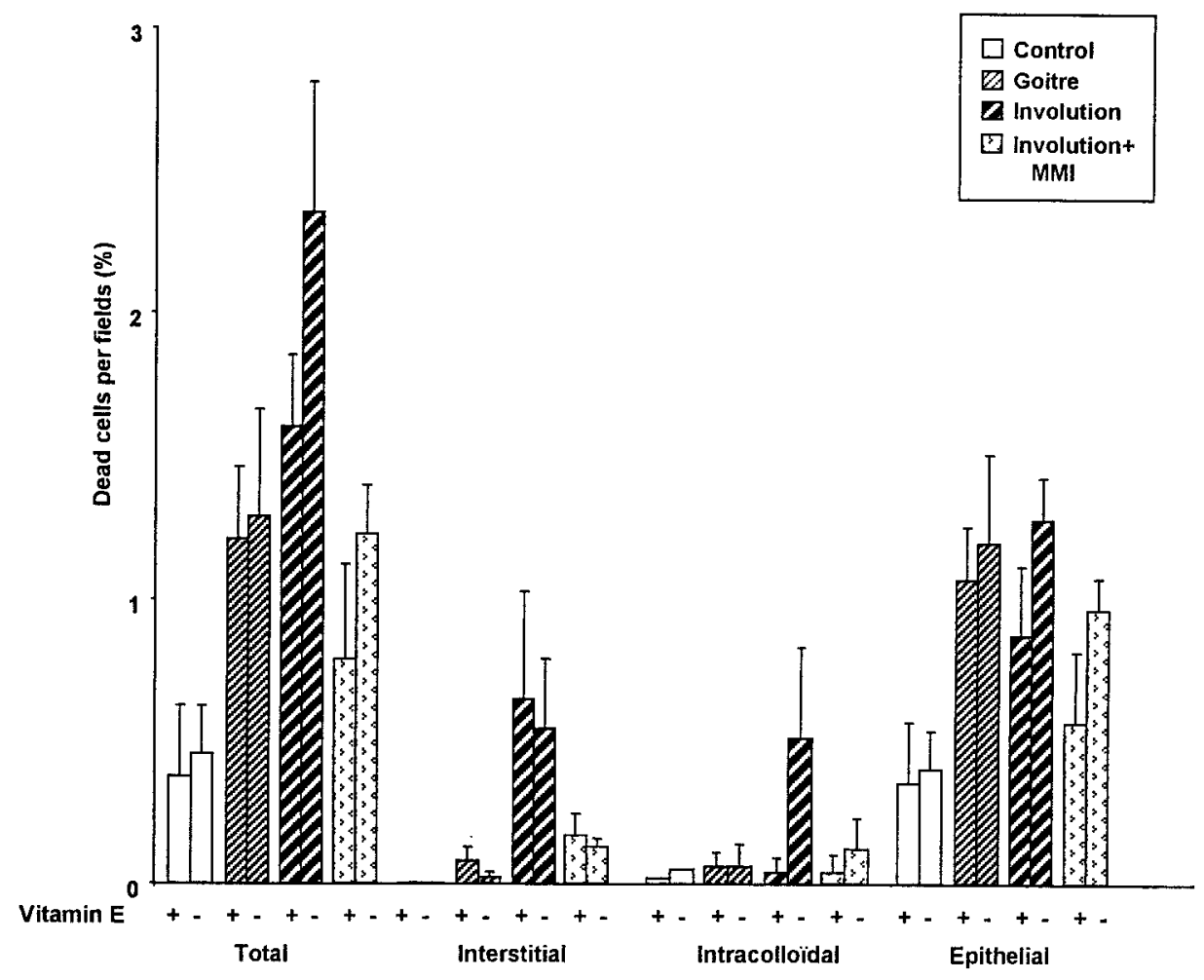

\section{$B$ : Epithelial death type}

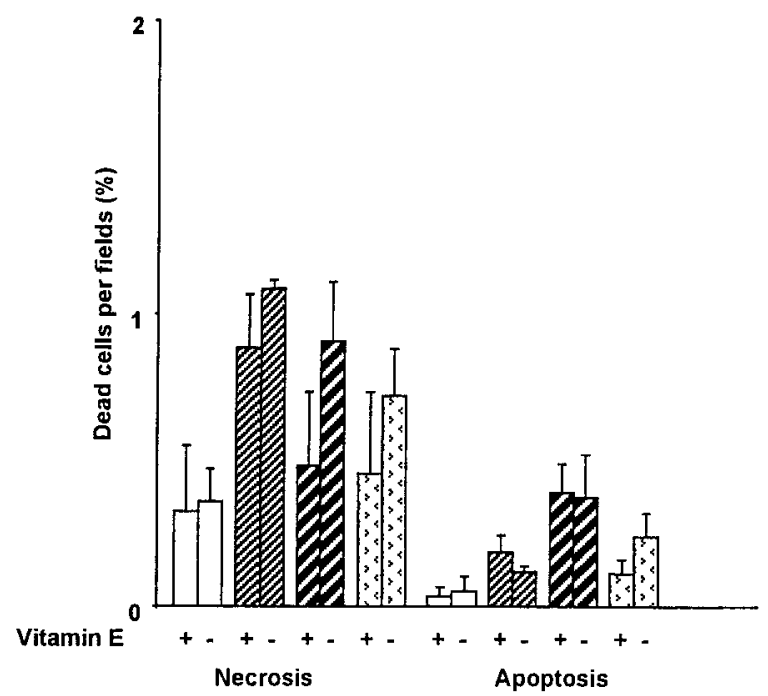

Figure 3 Quantification of various aspects of total dead cells (A) and epithelial death type (B). $E^{+}$and $\mathrm{E}^{-}$rats were either untreated (control group), made goitrous by drinking perchlorate (goitre group), further injected with $\mathrm{Nal}$ alone (involution group) or with MMI (involution+MMI group). There were $\sim 100$ cells/field. Means \pm S.D., $n=5$. Results of statistical analysis were as follows. Total number of dead cells: vitamin effect: significant for $P<0 \cdot 001$; treatment effect: $P<0 \cdot 001$; interaction: $P<0 \cdot 05$. Number of interstitial dead cells: vitamin effect: ns; treatment effect: $P<0 \cdot 001$; interaction: ns. Number of epithelial dead cells: vitamin effect: $P<0 \cdot 001$; treatment effect: $P<0 \cdot 001$; interaction: ns. Epithelial necrotic cells: vitamin effect: $P<0 \cdot 01$; treatment effect: $P<0 \cdot 001$; interaction: ns. Epithelial apoptotic cells: vitamin effect: ns; treatment effect: $P<0 \cdot 05$; interaction: ns. 
Table 3 Caspase-3/apopain activity (means \pm S.D., $n=4$ ). Same protocol as in Table 1

\begin{tabular}{|c|c|c|}
\hline & Vitamin E & $\begin{array}{l}\text { Caspase-3/apopain activity } \\
\text { (fmol } \mathrm{AFC} / \text { min per } \mu \mathrm{g} \mathrm{DNA})\end{array}$ \\
\hline \multicolumn{3}{|l|}{ Group } \\
\hline \multirow[t]{2}{*}{ Control } & + & ND \\
\hline & - & ND \\
\hline \multirow[t]{2}{*}{ Goitre } & + & $135 \pm 8 \cdot 2$ \\
\hline & - & $184 \pm 2 \cdot 4$ \\
\hline \multirow[t]{2}{*}{ Involution } & + & $242 \pm 33$ \\
\hline & - & $208 \pm 58$ \\
\hline
\end{tabular}

ANOVA analysis shows a significant difference $(P<0 \cdot 01)$ between the goitre and the involution groups. $\mathrm{ND}=$ not detected. Data represent fmol of 7-amino-4-trifluoromethyl coumarin (AFC) released from the fluorogenic peptide substrate carbobenzoxy-DEVD-AFC.

\section{Discussion}

We present here direct evidence for a different involvement of necrosis and apoptosis in the thyroid cell death occurring during goitre development and its aggravation upon involution. During goitre development, necrosis of
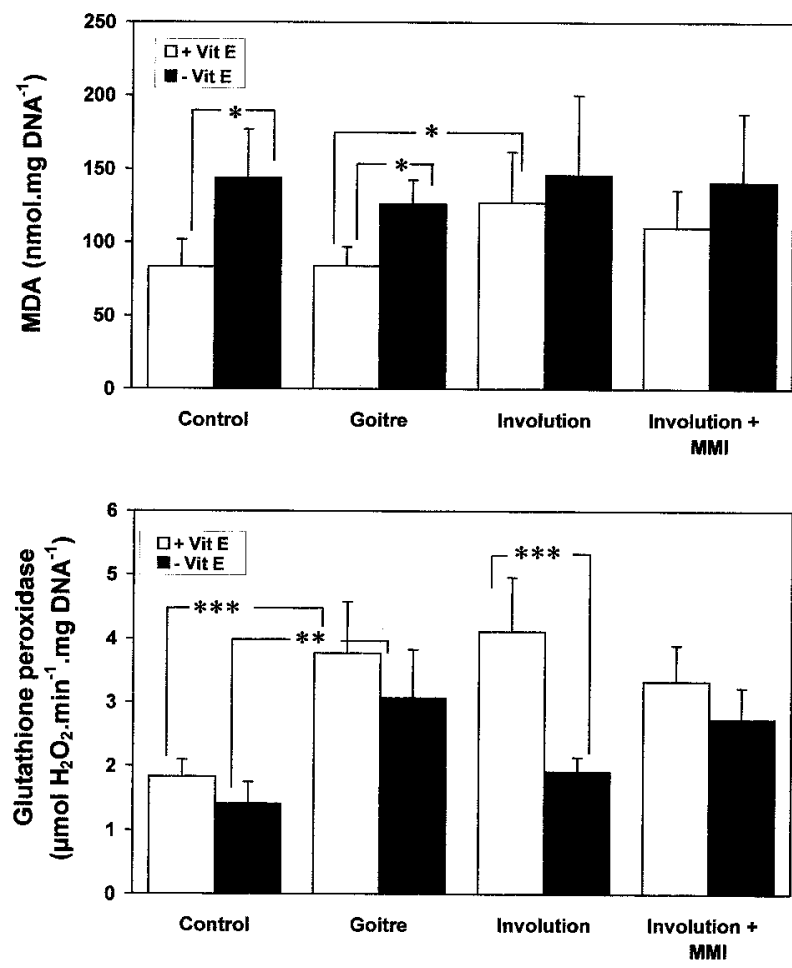

Figure 4 Oxidation index and antioxidant potential. Thyroid malondialdehyde (MDA) concentrations (upper panel) and glutathione peroxidase (GPx) activities (lower panel) were determined. For details of the experimental groups, see legend of Fig. 3. ${ }^{*} P<0 \cdot 05,{ }^{*} P<0 \cdot 01,{ }^{* *} P<0 \cdot 001$ vs the similar experimental group with different vitamin $E$ supply or the different experimental group with similar vitamin E supply. thyrocytes increases to a much larger extent than apoptosis. On the contrary, apoptosis is predominantly stimulated during iodine-induced involution. In addition, necrosis but not epithelial or interstitial apoptosis is significantly increased upon vitamin E deficiency, i.e. when the antioxidative defences were reduced, as reflected by the increase in MDA concentrations and the decline in GPx activity.

\section{Vitamin E deficiency reduces antioxidative protection}

Vitamin E, which is very active in the antioxidative protection of thyroid membrane, is as concentrated in the thyroid as in the liver in control rats and 2-fold increased in goitres (Mutaku et al. 1998). We therefore have developed a model of experimental goitre in animals with reduced antioxidative defences to test the hypothesis of a reactive oxygen-induced cell death during goitre development and involution. Our results clearly show that vitamin $\mathrm{E}$ deficiency is associated with an increase in MDA concentration and a decrease in GPx activity in the thyroid and a concomitant rise of MDA in the liver. These results, in line with others (Bourre et al. 2000), reflect a systemic defect in antioxidative protection.

In addition to its antioxidative effect, vitamin $\mathrm{E}$ also has other actions; vitamin E-deficient animals have a depressed growth rate (Machlin et al. 1977), possibly through abnormalities of the growth hormone-insulin-like growth factor system. In the present study, vitamin E-deficient rats, despite a comparable daily food intake, gained less body weight than rats fed a control diet, with a parallel reduction of the thyroid weight.

\section{Vitamin E deficiency aggravates total and epithelial cell death}

We show here that total cell death count, known to increase during goitre development in mice (Many et al. 1991) and rats (Contempré et al. 1993, Mutaku et al. 1998), is further increased after iodide administration to iodine-deficient rats. These changes are in line with previous reports (Mahmoud et al. 1986, Many et al. 1991, 1992, 1995, Contempré et al. 1993, 1995, Mutaku et al. 1998). However, it can be added that this iodine-induced increase results mostly from the appearance of dead cells in the interstitium, all with pyknotic nuclei, in $\mathrm{E}^{-}$as well as in $\mathrm{E}^{+}$animals. In contrast, the number of epithelial dead cells was not influenced by the iodine load but, as a whole, significantly increased with vitamin E deficiency.

The present work, for the first time, separates quantification of apoptotic and necrotic cells in goitre and after administration of a pharmacological dose of iodine. It clearly shows that necrosis predominates in the goitrous gland, while apoptosis is significantly induced during goitre involution. 
Apoptosis occurs during goitre involution and is not influenced by vitamin E status

Apoptosis, as assessed by measurement of TUNELpositive cells, increased during goitre formation in experimental rats (Tamura et al. 1998). The reliability of this method is questionable when apoptosis is to be compared with necrosis. Indeed, the TUNEL method is based on the incorporation of labelled nucleotides into DNA breaks and can yield false positive results due to other mechanisms of DNA nicking such as during necrosis. In addition, methodological artefacts can be induced by aldehyde fixation (Labat-Moleur et al. 1998). We, therefore, decided to quantify instead apoptosis by careful histological counting of cells with pyknotic nuclei or apoptotic bodies. Using this method, we show that apoptosis of epithelial cells, which is exceptionally detected in normal thyroids, already slightly increased during goitre development. In contrast, a high iodine load rapidly induces the occurrence of pyknotic thyrocytes and apoptotic bodies at the basal pole of normal cells, indicating the participation of this type of cell death in the goitre regression. The increase of the caspase-3/apopain activity during involution confirmed these results at the molecular level.

The occurrence of apoptotic cells in the interstitium could reflect a totally different mechanism, even if apoptotic epithelial cells could extrude out of the epithelial layer. Some interstitial apoptotic cells are probably inflammatory in nature, as a consequence of the small inflammatory reaction induced by the iodine treatment; they could also be mast cells, although lymphocytes and mast cells are few. Other apoptotic cells are most probably of endothelial nature, reflecting the involution of the vascular bed. An apoptosis-specific protein was also immunolocalized predominantly in the stromal and vascular tissue (Patel et al. 2000).

Both the morphological counting and the direct detection of the caspase-3/apopain activity show that apoptosis evolves in the epithelium or in the interstitium independently of the vitamin $\mathrm{E}$ status of the animals, indicating that it is not modulated by the cellular antioxidative defences. This contrasts with experiments carried out in vitro, suggesting a role of free radical generation in apoptosis induction. In the first study, addition of $\mathrm{H}_{2} \mathrm{O}_{2}$ to primary cultures of pig thyrocytes was reported to cause apoptosis with modifications of the Bcl-2/Bax regulatory pathway (Riou et al. 1999), and a decreased response in FRTL-5 cells overexpressing peroxiredoxins (Kim et al. 2000). The discrepancy with our results could be that either $\mathrm{H}_{2} \mathrm{O}_{2}$ concentration in the goitrous glands analysed remained much below the high concentration applied to thyrocytes in vitro, or that $\mathrm{H}_{2} \mathrm{O}_{2}$ takes no part in the iodine-induced apoptosis. In a second study, excess molecular iodine induced apoptosis in isolated thyrocytes independently of the modulation of $\mathrm{Bcl}-2$ or Bax protein expression or protein synthesis, but through generation of free radicals (Vitale et al. 2000). However, in that study, the iodine-induced cytotoxicity included necrotic and apoptotic features in equal proportions and arguments for an implication of free radicals in apoptosis were only circumstantial. As in our study, apoptosis was fully blocked by an inhibitor of thyroperoxidase, indicating a role for molecular iodine.

\section{Vitamin E deficiency aggravates epithelial cell necrosis}

We show here that cells with necrotic features are almost exclusively epithelial cells. They are, as a whole, more numerous in $\mathrm{E}^{-}$than in $\mathrm{E}^{+}$thyroids and no more numerous after a high iodine load. Reports on the effect of iodine on cell necrosis are discrepant, depending on the experimental model used. Indeed, necrosis is less extensive in male Wistar rats used in our study than in mice (Mahmoud et al. 1986, Many et al. 1991) or other species (Belshaw \& Becker 1973, Bagchi et al. 1995), and several authors did not even observe necrotic thyrocytes in rats (Allen 1992, Li \& Boyages 1994, Colzani et al. 1999). However, most of these studies were performed in rats fed a normal iodine dose (Allen 1992, Li \& Boyages 1994). In a study by another group on iodine-deficient female rats, an iodide dose ten times as large as in the present study did also not result in increased cell death (Colzani et al. 1999). The fact that serum $\mathrm{T}_{4}$ and TSH concentrations were not modified in their study, in contrast to ours, suggests that iodine has to be in its oxidized form to be toxic. Discrepancy could originate from species- or genderlinked variations either in the antioxidative defences, or in the avidity of thyroid cells for iodide. Indeed, in the mouse fed a normal iodine diet, administration of large doses of iodine does not provoke cell necrosis (Many et al. 1995).

Necrosis affected isolated cells and not pluricellular foci, as would be expected in the case of severe toxicity. It could therefore be interpreted as the consequence of a locally produced and rapidly degraded toxic agent, such as $\mathrm{H}_{2} \mathrm{O}_{2}$ produced in excess at the apical membrane of goitrous glands. Indeed, necrosis of epithelial cells is increased in vitamin $\mathrm{E}^{-}$thyrocytes in which the reduced GPx activity could become limiting in some cells. These results support the free radical hypothesis previously proposed (Denef et al. 1996). Since the 2 -fold increase in vitamin $\mathrm{E}$ content of goitres (Mutaku et al. 1998) is less than that of $\mathrm{H}_{2} \mathrm{O}_{2}$ production (Corvilain et al. 1991), the administration of a vitamin E supplement to goitrous patients will improve their antioxidative defences.

Vitamin E deficiency induces the intracolloidal accumulation of cell debris during goitre involution

After goitre involution, cell fragments accumulate in the follicular lumen of vitamin $\mathrm{E}^{-}$thyroids while they are very rare in vitamin $\mathrm{E}^{+}$colloids. Whether those 
fragments represent terminal necrotic debris or apoptotic bodies expelled apically could not be decided. However, their presence essentially in vitamin E-deficient animals suggests that the integrity of the apical membrane could have been perturbed in this situation of high membrane peroxidation.

\section{Conclusion}

In conclusion, two types of cell death, necrosis and apoptosis, occur during goitre development and involution. They are differently modulated according to the oxidative status and/or the level of stimulation of the thyroid gland. Necrosis is related to the oxidative status of the thyroid cells while apoptosis occurs with iodine-induced involution.

\section{Acknowledgements}

M-F V D H is a Research Associate of the National Fund for Scientific Research (Belgium). We are grateful to $\mathrm{M}$ Eppe, T Lac and M Parisi for their excellent technical assistance and to $\mathrm{Y}$ Marchand for the preparation of the manuscript. This work was supported by the Fonds de la recherche scientifique médicale (FRSM) (grants No. 3.4590.92 and 3.4506.96) and by the Belgium StatePrime Minister's Office-Science Police Programming (IUAP). We acknowledge the Secrétariat à la Coopération Internationale and the Service d'Aide aux Etudiants of the Catholic University of Louvain. We appreciate Prof. $P$ Courtoy's critical reading and suggestions for improvement of this manuscript.

\section{References}

Allen EM 1992 The effect of iodine on lipid peroxidation and ultrastructure in the thyroids of $\mathrm{BB} / \mathrm{W}$ rats. Journal of Endocrinological Investigation 15 519-523.

Bagchi N, Brown TR \& Sundick RS 1995 Thyroid cell injury is an initial event in the induction of autoimmune thyroiditis by iodine in obese strain chickens. Endocrinology 136 5054-5060.

Bechtner G, Fröschl H, Sachse A, Schopohl D \& Gärtner R 1999 Induction of apoptosis in porcine thyroid follicles by transforming growth factor $\beta 1$ and epidermal growth factor. Biochimie $\mathbf{8 1}$ 315-320.

Belshaw B \& Becker DV 1973 Necrosis of follicular cells and discharge of thyroidal iodine induced by administering iodide to iodine-deficient dogs. Journal of Clinical Endocrinology and Metabolism 36 466-474.

Bidder TG \& Sipka BM 1989 A modification of the thiobarbituric acid reaction. Lipids 24 656-658.

Björkman U \& Ekholm R 1995 Hydrogen peroxide degradation and glutathione peroxidase activity in cultures of thyroid cells. Molecular and Cellular Endocrinology 111 99-107.

Bourre J, Dumont O, Clement M, Dinh L, Droy-Lefaix M \& Christen Y 2000 Vitamin E deficiency has different effects on brain and liver phospholipid hydroperoxide glutathione peroxidase activities in the rat. Neuroscience Letters 268 87-90.
Bretz JD, Arscott PL, Myc A \& Baker JR 1999 Inflammatory cytokine regulation of Fas-mediated apoptosis in thyroid follicular cells. Journal of Biological Chemistry 274 25433-25438.

Colzani RM, Sharon A, Shin-Lieh F, Scott S \& Braverman LE 1999 Effects of iodine repletion on thyroid morphology in iodine and/or selenium deficient rat term fetuses, pups and mothers. Biochimie $\mathbf{8 1}$ 485-491.

Contempré B, Denef J-F, Dumont JE \& Many M-C 1993 Selenium deficiency aggravates the necrotizing effects of a high iodide dose in iodine deficient rat. Endocrinology 132 1866-1868.

Contempré B, Dumont JE, Denef J-F \& Many M-C 1995 Effects of selenium deficiency on thyroid necrosis, fibrosis and proliferation: a possible role in myxoedematous cretinism. European Journal of Endocrinology 133 99-109.

Corvilain B, Van Sande J, Laurent E \& Dumont JE 1991 The $\mathrm{H}_{2} \mathrm{O}_{2}$-generating system modulates protein iodination and the activity of the pentose phosphate pathway in the thyroid. Endocrinology 128 779-785.

Denef J-F, Haumont S, Cornette C \& Beckers C 1981 Correlated functional and morphometric study of thyroid hyperplasia induced by iodine deficiency. Endocrinology 108 2352-2358.

Denef J-F, Many M-C \& van den Hove M-F 1996 Iodine-induced thyroid inhibition and cell necrosis: two consequences of the same free-radical mediated mechanism? Molecular and Cellular Endocrinology 121 101-103.

Derwahl M \& Studer H 1998 Pathogenesis and treatment of multinodular goiter. In Thyroid Cancer, pp 155-186. Ed. JA Fagin. Boston: Kluwer Academic.

Di Matola T, Mueller F, Fenzi G, Rossi G, Bifulco M, Marzano LA \& Vitale M 2000 Serum withdrawal-induced apoptosis in thyroid cells is caused by loss of fibronectin-integrin association. Journal of Clinical Endocrinology and Metabolism 85 1188-1193.

Dremier S, Golstein J, Dumont JE, Galand P \& Robaye B 1994 Apoptosis in dog thyroid cells. Biochemical and Biophysical Research Communications 200 52-58.

Dumont JE, Lamy F, Roger P \& Maenhaut C 1992 Physiological and pathological regulation of thyroid cell proliferation and differentiation by thyrotropin and other factors. Physiological Reviews 72 667-697.

Ekholm R \& Björkman U 1997 Glutathione peroxidase degrades intracellular hydrogen peroxide and thereby inhibits intracellular protein iodination in thyroid epithelium. Endocrinology $\mathbf{1 3 8}$ 2871-2878.

Feldkamp J, Pascher E, Perniok A \& Scherbaum WA 1999 Fas-mediated apoptosis is inhibited by TSH and iodine in moderate concentrations in primary human thyrocytes in vitro. Hormone and Metabolic Research 31 355-358.

Follis RH 1964 Further observations on thyroiditis and colloid accumulation in hyperplastic thyroid glands of hamsters receiving excess iodine. Laboratory Investigation 13 1590-1599.

Gutteridge JMC 1978 Membrane effects of vitamin E, cholesterol and other acetates on peroxidative susceptibility. Research Communications in Chemical Pathology and Pharmacology 22 563-572.

van den Hove M-F, Couvreur M, Col V, Gervy C, Authelet M \& Nève P $1995 \mathrm{~T}_{4}$ accumulation in lysosomes of rat thyroid remnants after subtotal thyroidectomy. European Journal of Cell Biology 68 437-445.

van den Hove-Vandenbroucke M-F, Santisteban P, Couvreur M, Obregon MJ \& Lamas L 1982 Involution of rat iodoprive hyperplastic goiter: effect of iodide administration on thyroid function and lysosomal properties. Endocrinology 10 1812-1818.

Kawakami A, Eguchi K, Matsuoka N, Tsuboi M, Kawabe Y, Ishikawa N, Ito K \& Nagataki S 1996 Thyroid-stimulating hormone inhibits Fas antigen-mediated apoptosis of human thyrocytes in vitro. Endocrinology 137 3163-3169.

Kim H, Lee T-H, Park ES, Suh JM, Park SJ, Chung HK, Kwon O-Y, Kim YK, Ro HK \& Shong M 2000 Role of peroxiredoxins 
in regulating intracellular hydrogen peroxide and hydrogen peroxide-induced apoptosis in thyroid cells. Journal of Biological Chemistry 275 18266-18270.

Knoops B, Clippe A, Bogard C, Arsalane K, Wattiez R, Hermans C, Duconseille E, Falmagne P \& Bernard A 1999 Cloning and characterization of AOEB166, a novel mammalian antioxidant enzyme of the peroxiredoxin family. Journal of Biological Chemistry 274 30451-30458.

Kotani T, Aratake K, Hirai K, Fukazawa Y \& Ohtaki S 1995 Apoptosis in thyroid tissue from patients with Hashimoto's thyroiditis. Autoimmunity 20 231-236.

Labat-Moleur F, Guillermet C, Lorimier P, Robert C, Lantuejoul S, Brambilla E \& Negoescu A 1998 TUNEL apoptotic cell detection in tissue sections: critical evaluation and improvement. Journal of Histochemistry and Cytochemistry 46 327-334.

Li M \& Boyages SC 1994 Iodide induced lymphocytic thyroiditis in the $\mathrm{BB} / \mathrm{W}$ rat: evidence of direct toxic effects of iodide on thyroid subcellular structure. Autoimmunity 18 31-40.

Li X, Miyagi E, Katoh R \& Kawaoi A 1999 Thyrotropin prevents apoptosis by promoting cell adhesion and cell cycle progression in FRTL-5 cells. Endocrinology 140 5962-5970.

Machlin LJ, Filipski R, Nelson J, Horn LR \& Brin M 1977 Effects of a prolonged vitamin $\mathrm{E}$ deficiency in the rat. Journal of Nutrition 107 1200-1208.

Mahmoud I, Colin I, Many M-C \& Denef J-F 1986 Direct toxic effect of iodide in excess on iodine-deficient thyroid glands: epithelial necrosis and inflammation associated with lipofuscin accumulation. Experimental and Molecular Pathology 44 259-271.

Mano T, Shinohara R, Iwase K, Kotake M, Hamada M, Uchimura K, Hayakawa N, Hayashi R, Nakai A, Ishizuki Y \& Nagasaga A 1997 Change in free radical scavengers and lipid peroxide in thyroid glands of various thyroid disorders. Hormone and Metabolic Research 29 351-354.

Many M-C, Papadopoulos J, Martin C, Colin I \& Denef J-F 1991 Iodine induced cell damage in mouse hyperplastic thyroid is associated to lipid peroxidation. In Progress in Thyroid Research, pp 635-638. Eds A Gordon, J Gross \& G Hennemann. Rotterdam: Balkema.

Many M-C, Mestdagh C, van den Hove M-F \& Denef J-F 1992 In vitro study of acute toxic effects of high iodide doses in human thyroid follicles. Endocrinology 131 621-630.

Many M-C, Maniratunga S, Varis I, Dardenne M, Drexhage HA \& Denef J-F 1995 Two-step development of Hashimoto-like thyroiditis in genetically autoimmune prone non-obese diabetic mice: effects of iodine-induced cell necrosis. Journal of Endocrinology 147 311-320.

Mutaku JF, Many M-C, Colin I, Denef J-F \& van den Hove M-F 1998 Antigoitrogenic effect of combined supplementation with $\mathrm{dl}-\alpha$-tocopherol, ascorbic acid and $\beta$-carotene and $\mathrm{dl}-\alpha$-tocopherol alone in the rat. Journal of Endocrinology 156 551-561.

Patel VA, Hill DJ, Sheppard MC, Wang J-F, Logan A \& Eggo MC 2000 Apoptosis during goitre involution - the role of Bcl-2. Journal of Endocrinology 164 323-330.

Riou C, Tonoli H, Bernier-Valentin F, Rabilloud R, Fontlupt P \& Rousset B 1999 Susceptibility of differentiated thyrocytes in primary culture to undergo apoptosis after exposure to hydrogen peroxide: relation with the level of expression of apoptosis regulatory proteins, Bcl-2 and Bax. Endocrinology 140 1990-1997.

Rognoni JB, Penel C, Golstein J, Galand P \& Dumont JE 1987 Cell kinetics of thyroid epithelial cells during hyperplastic goitre involution. Journal of Endocrinology 114 483-490.

Sato H, Abe Y, Noguchi M, Kurokawa K \& Sakai H 1999 Inhibitory effect of thyrotropic hormone on apoptosis induced by actinomycin $\mathrm{D}$ in a functioning rat thyroid cell line. Endocrine Journal 46 309-315.

Tamura M, Kimura H, Koji T, Tominaga T, Ashiwaza K, Kiriyama T, Yokoyama N, Yoshimura T, Eguchi K, Nakane P \& Nagataki S 1998 Role of apoptosis of thyrocytes in a rat model of goiter. Endocrinology 139 3646-3653.

Tanimoto C, Hirakawa S, Kawasaki H, Hayakawa N \& Ota Z 1995 Apoptosis in thyroid diseases: a histochemical study. Endocrine Journal 42 193-201.

Vitale M, Di Matola T, D’Ascoli F, Salzano S, Bogazzi F, Fenzi G, Martino E \& Rossi G 2000 Iodide excess induces apoptosis in thyroid cells through a p53-independent mechanism involving oxidative stress. Endocrinology 141 598-605.

Walsh DM, Kennedy S, Blancheflower WJ, Goodall EA \& Kennedy DG 1993 Vitamin E and selenium deficiencies increase indices of lipid peroxidation in muscle tissue of ruminant calves. International Journal for Vitamin and Nutrition Research 63 188-194.

Wollman SH, Andros G, Cannon GB \& Eagleton GB 1968 Production and involution of the hyperplastic thyroid gland. In Thyroid Neoplasia, pp 201-209. Eds S Young \& DR Inman. London: Academic Press.

Received in final form 3 October 2001 Accepted 22 October 2001 